\title{
Chondromyxoid Fibroma
}

National Cancer Institute

\section{Source}

National Cancer Institute. Chondromyxoid Fibroma. NCI Thesaurus. Code C3830.

An uncommon benign cartilaginous neoplasm arising from the bone. It is characterized by the presence of spindle-shaped or stellate chondrocytes, a lobulated growth pattern, myxoid stroma formation, and sometimes multinucleated giant cells. It has been associated with chromosomal rearrangement of $6 q 13$ and $6 q 25$ bands. The most common clinical symptom is mild, localized pain. 